\title{
Dealing with Deportability: Deportation Laws and the Political Personhood of Temporary Migrant Workers in Singapore
}

\author{
Charanpal S. BAL*
}

Visiting Lecturer, Faculty of Social and Political Science, Parahyangan Catholic University, Bandung, and Associate, Asia Research Centre, Murdoch University, Western Australia.

\begin{abstract}
By severely constraining the political personhood of temporary migrant workers, states' use of deportation laws seeks to curb agitation among these workers. Despite this, various episodes of unrest have been witnessed in both liberal and illiberal regimes across Asia. Drawing on a case study of Bangladeshi migrant construction workers in Singapore, this paper examines the development of migrant labour politics as deportation laws, and their enforcement, construct these workers as "use-and-discard" economic subjects. Data for the paper are drawn from multi-level sources-government, industry, media, and non-governmental organization (NGO) reports; interviews with key actors; and a participant observation stint in a construction firm-collected between 2010 and 2014. The paper argues that, rather than solely constraining, deportability serves as a constituent of certain forms of tactical worker contestations in the workplace. Specifically, under different workplace conditions, deportability can translate into differing forms of worker tactics, ranging from accommodation to confrontation and desertion. The outcomes of these strategies, in turn, have significant repercussions for the ways in which civil society groups and state-actors, respectively, challenge and reconfigure the political personhood of temporary migrant workers.
\end{abstract}

Keywords: temporary migrant workers, deportation, political personhood, migrant labour politics, Singapore

\section{INTRODUCTION}

Deportation laws are a key feature of guest-worker regimes around the world. They are a crucial part of a legal order enacted by labour-receiving states to ensure that migrant workers remain temporary and disposable despite constituting a permanent feature of these economies. Temporary migrants are only permitted to remain within recipient societies as long as they are economically required, as states afford employers the freedom to terminate their

* Charan Bal is a Visiting Lecturer at the Faculty of Social and Political Science in the Parahyangan Catholic University, Bandung. He completed his PhD in Politics at Murdoch University's Asia Research Centre in November 2013. He researches on migrant labour politics in Asia. The author would like to thank Lynette Chua, Daniel Goh, Garry Rodan, and Jane Hutchison for the support and constructive suggestions they have made in the research and writing of this paper. Thanks also go to the two anonymous reviewers for their constructive suggestions and comments. The usual disclaimers apply. Correspondence to No. 10, Jalan Hegarsari III, Hegarmanah, Bandung 40141, Indonesia. E-mail address: charanpal.s.bal@gmail.com. 
employment regardless of the legally sanctioned length-of-work tenure. The personhood of temporary migrant workers is, thus, constructed by states, through deportation laws, as disposable economic subjects with few or no political rights.

The existing literature on migrant labour politics accordingly indicates that such a legal order enforced by states undermines or even negates the political personhood of temporary migrant workers. Deportation laws may preclude workers from certain rights available to citizens and residents (such as rights to political representation) or may obstruct then from accessing the few rights that they may be afforded by states (such as economic rights). ${ }^{1}$ It is also argued that the undermining of their political personhood through deportation laws impedes struggles for the protection and promotion of migrants' economic and political interests. $^{2}$ Yet, at the same time, various episodes of migrant labour unrest have been witnessed in many recipient countries with both relatively open and illiberal political systems. Such episodes of unrest have resulted in not only the use of deportations to quell unrest, but also significant reforms to employment and immigration laws. These observations suggest that it is necessary to look beyond the constraining effects of deportation laws and to examine how these laws constitute and engender the contextual nature of struggles for migrant worker rights.

Using the case of Bangladeshi temporary migrant workers in Singapore's construction industry, this article investigates how deportation laws and their application influence the nature of contestations over the political personhood of these workers. I focus on how the deportable status of these workers as well as threats and practices of deportation influence the formation of tactics used to address worker grievances in the workplace. In contrast to existing perspectives, I take deportability as a constituent, rather than simply an impediment, to prevalent forms of workplace politics. Consequently, I argue that different forms of workplace politics-ranging from accommodation to confrontation and desertioninfluence how well civil society groups are able to contest state constructions of migrant workers as disposable economic subjects. I further argue that minor policy reforms, resulting from migrant labour unrest and civil society pressure, emphasize individual over collective political rights in order to administratively depoliticize tensions between migrant workers and employers over working conditions.

The following section clarifies the concept of deportability and examines the way it shapes both the personhood and politics of temporary migrant workers. Section 2 describes the methods and data used for the analysis while Section 3 provides an overview of deportation laws and practices in Singapore. In Section 4, I highlight key aspects of the construction workplace in Singapore as the context within migrant workers experience vulnerability to deportation as well as discontent with working conditions. Sections 5 and 6 explicitly deal with the micro-politics of production. Section 5 demonstrates how factors relating to production geography and employer strategies allow workers to mitigate their vulnerability to deportation whilst simultaneously trying to improve their working conditions on an informal and individualized basis. Section 6 examines how this form of tactical accommodation breaks down and escalates into disputes, confrontation, forced deportation, and, eventually, worker desertion. Finally, Section 7 examines the link between worker desertion and civil society efforts in

1. Castells (1975); Sassen-Koob (1981); Arnold \& Hewison (2006).

2. Castles \& Kosack (1973); Binford (2009). 
contesting migrant labour laws, particularly those relating to the deportability of migrant workers. The penultimate section also draws out the broader implications of authorities making limited expansions to the political personhood of these workers.

\section{DEPORTABILITY, POLITICAL PERSONHOOD, AND MIGRANT LABOUR POLITICS}

Deportability is related to but distinct from actual practices of deportation. This article deals with both these aspects. While the forced deportation of migrant workers by government authorities and employers often serves to regulate labour supply or stymie labour agitation within host societies, it is the deportable legal status of these temporary migrants that renders their labour power a "distinctly disposable commodity." 3 At the same time, deportation laws intersect with a host of related factors-deprivation of citizenship rights, occupational immobility, inability to access trade union movements, and high recruitment debt- to make guest workers both tractable and vulnerable, allowing state authorities and employers greater leeway in politically controlling the migrant workforce.

In this sense, deportation laws render temporary migrant workers as "use-and-discard" disposable economic subjects rather than political persons who are "bearer[s] or rights ... [who] can hold values, make choices." ${ }^{, 5}$ On paper at least, states tend to afford these migrants a limited range of economic rights. In Singapore, for instance, temporary migrant workers have the right to prompt payment of wages, overtime and rest-day pay rates, pro-rated annual leave, severance payments in lieu of notice, and work-injury compensation. In Malaysia, they are even entitled to the same minimum wage as citizens. Many states also allow workers to lodge formal claims and complaints in order to have these economic rights enforced. These limited rights only allow workers to politically participate as individual complainants within statesanctioned bureaucratic spaces rather than as autonomous and collective political actors.

At the same time, the deportable status of these workers as well as state/employer practices of forced removal inhibits or precludes them from accessing these few rights that they have been afforded. Their vulnerability to forced deportation at the whims of authorities and employers means that they face significant obstacles in enforcing these economic rights as individual complainants. In other words, their deportability and deportation practices mean that the few rights that they have on paper do not often get enforced in practice. Furthermore, the limited rights that they have do not sufficiently address the various issues that they face in host societies such as low wages, debt bondage, and arbitrary termination of employment. In this sense, deportation laws undermine the political personhood of temporary migrant workers by effectively disallowing them from any form of meaningful political participation of contestation within host societies.

The literature on migrant labour politics accordingly argues that these laws impede struggles for the protection and promotion of migrants' economic and political interests. ${ }^{6}$ As a

3. de Genova (2005), p. 8; Liow (2011), p. 14.

4. Yeoh (2006), p. 32

5. Taylor (1985), p. 97.

6. Castles \& Kosack, supra note 2; Castells, supra note 1; Sassen-Koob, supra note 1; Arnold \& Hewison, supra note 1; Binford, supra note 2. 
consequence, particular segments of capital are able to benefit from "cheap" and easily controllable workers who are unlikely to resist exploitation and abuse. Based on a study of contract Mexican farm labour in Canada, Binford points out that, while discontent at working conditions among migrant workers exist, it develops "under ... severe structural constraints" and the potential for collective resistance tends to impeded by possible and actual practices of forced deportation of suspected "ringleaders" of wildcat strikes. ${ }^{7}$ In short, the literature argues that deportation laws ensure that migrant workers struggles are politically constrained because they have few formal rights to influence the institutions that subordinate them. Deportation laws, therefore, represent a form of structural coercion that limits or impedes the spaces that migrant workers have to resist or contest the exploitation and abuse that they face at work.

In spite of such laws, protests, strikes, and riots by migrant workers have been witnessed in many labour-importing countries across Asia such as Hong Kong, Singapore, Malaysia, and several Gulf states. ${ }^{8}$ It is of note that such unrest has been reported in both countries with relatively open (Hong Kong) political systems which offer guest workers relatively more political freedoms as well as in countries with illiberal or autocratic political systems (Singapore, Malaysia, and the Gulf states) whose states tend to severely inhibit any form of collective mobilization. While authorities in these states have shown a willingness to use forced deportation to quell unrest, they have also made modest but significant political concessions to migrant workers by way of reforms to migrant labour laws. Authorities in Dubai, for instance, moved to legalize strike action insofar as they are confined within individual labour camps. ${ }^{9}$ In the wake of migrant labour unrest and civil society pressure during the Global Financial Crisis (GFC) in 2008/09, authorities in Singapore opened up further avenues for individual claims and complaints by illegalizing kickbacks and instituting compulsory no-work pay. ${ }^{10}$

Such developments indicate that deportation laws may do more than simply impede struggles for migrant labour rights. Using the Singapore case, I examine how deportability and deportation laws both constrain and engender certain forms of political contestations. Specifically, I focus on the micro-politics of production as the site where workers deal with their consequent vulnerability by resorting to a range of tactics from accommodation to confrontation and desertion. The manner in which these worker tactics play out, in turn, have significant repercussions for the extent to which civil society groups are able to contest state constructions of temporary migrant workers as disposable economic subjects. Finally, the small-scale reforms to migrant labour laws are examined for how they mitigate the deportability of guest workers by expanding the scope for individualized administrative complaints in order to depoliticize existing workplace tensions.

\section{DATA AND METHODS}

Data for this paper were drawn from a number of multi-level sources between 2010 and 2014. Between October 2010 and May 2012, I conducted in-depth interviews with 45 Bangladeshi migrant workers who were working or had worked in Singapore as semi- or

7. Binford, ibid., pp. 512-17.

8. Hsia (2009); Buckley (2013); Bal (2015).

9. Buckley, ibid.

10. Bal, supra note 8 . 
unskilled construction workers on work permits. These interviews covered a total of 103 work stints which focused on the production arrangements within construction sites and the employment experiences of these workers. At the time of the respective interviews, 22 respondents were currently employed in Singapore while ten of them were shelter residents seeking non-governmental organization (NGO) assistance for employment disputes with their employers. The other 13 respondents were return migrants who had previously worked in Singapore and were interviewed whilst they were in between jobs in Bangladesh. Despite their vulnerable position, my respondents spoke freely about their working conditions and episodes of conflict and tension at work that they thought were significant. The return migrants felt little fear of repercussions while those currently employed felt secure in their own tactics of dealing with deportability (see Section 3). The workers engaged in employment disputes, on the other hand, were even more eager to speak out against the treatment they received at the hands of their bosses and supervisors.

I also conducted a four-month participation observation stint at a local construction firm where I worked as steel fitter on pedestrian bridges, bus shelters, and walkways. While I was not deportable nor was I straddled with the debt that my co-workers had, the stint allowed me to directly observe how managerial control strategies were applied and manifested on a day-to-day basis. Together with the interview data, the data drawn from these observations were used to detail worker tactics in dealing with their deportability. Additionally, I collected 50 case-file documents from a local migrant worker NGO called the Humanitarian Organization for Migration Economics (HOME). These case files document the cases of legal assistance provided to workers from 2007 to 2011. Together with the interview data, these case files document how worker grievances turn into instances of confrontation and disputes. Both these sources also provided a fairly detailed documentation of practices of forced deportation and workers' efforts in escape and evasion. A number of secondary sources such as media, government, construction industry, and NGO reports were also used. Finally, targeted interviews were conducted with key informants such as contractors in Singapore and NGO staff and volunteers in order to fill particular gaps in the data.

\section{DEPORTATION LAWS AND FORCED DEPORTATION IN SINGAPORE}

The deportability of contract migrant workers in Singapore can be traced back to 1977 when immigration laws were enacted to make it an offence for non-resident employees to remain in the country upon the expiry of their work passes. ${ }^{11}$ In 1989, the criminalization of "overstaying" was intensified when the government introduced mandatory caning for workpermit holders who overstay their visas by more than 90 days. ${ }^{12}$ The enactment of the Employment of Foreign Manpower Act (EFMA) in 1991, which currently regulates the terms and conditions of the employment of semi- and unskilled guest workers, gave employers free rein to unilaterally terminate the work permits (and effectively, the employment) of migrant workers under their charge. ${ }^{13}$

\footnotetext{
11. No Author (1977).

12. No Author (1989)

13. Government of Singapore (1991).
} 
The enactment of EFMA by the government came about as construction contractors took to abandoning their guest workers mid-tenure in order to dodge rising foreign-worker levy rates imposed by the government from 1987. Guest-worker levies were introduced across several industries (construction, shipbuilding, and manufacturing) in 1987 as a pricing mechanism to force employers to adopt more capital-intensive production methods. Construction contractors, being largely small and medium-sized enterprises, did not have the means to invest in new machines and production techniques. They took to levy dodging, either by abandoning their migrant workers during business slumps or illegally employing these abandoned workers who had overstayed their visas. The government subsequently responded by incarcerating and deporting "overstayers" and prosecuting employers. At the height of this, in 1989 alone, these "overstayers" made up 17\% of the total prison population and cost S\$9.4 million a year to feed and clothe. ${ }^{14}$ Until 1991, it was the state that had to bear the cost of incarcerating and deporting migrant workers who had been left destitute by levy-dodging contactors.

With the enactment of EFMA that year, the legal responsibility of repatriating guest workers was put on to individual employers. The Act required all employers to put up an S\$5,000 bond with the Labour Ministry for every temporary migrant worker hired which would only be discharged upon the effective repatriation of the respective worker. A combination of immigration and labour laws ensure that responsibility of repatriating unwanted guest workers became the legal responsibility of the employer. Effectively, these laws endow employers the legal powers to terminate the employment of and deport guest workers under their employ at any given time.

In recent years, the state itself has used deportation to manage outbreaks of migrant labour unrest such as the SMRT Corporation bus drivers' strike in 2012 and the Little India riot in 2013. In both cases, only key figures involved in the disturbances were prosecuted and incarcerated. Most of the alleged participants were only subject to preliminary investigations and forcefully deported without trial. However, these were exceptional incidents as, long before this, employers have commonly taken advantage of deportation laws to forcefully repatriate their migrant workers. It is common for employers to terminate the employment of their workers and forcefully repatriate them when faced with real or anticipated worker insubordination or economic downturn.

A key aspect of these "everyday" practices of deportation is the use of repatriation companies. Repatriation companies in Singapore specialize in the repatriation of workpermit holders. They are not legally required to have a special license to operate. In 2005, there were between five and ten such companies in Singapore. ${ }^{15}$ These companies, known to most migrant workers simply as "gangsters," escort workers from the dormitory or worksite and hold them in custody at their premises until they are ready to be deported. The period of time workers are held at these premises can vary from a few hours to over a week. During this time, workers are confined and typically not allowed to leave and are physically and psychologically intimidated into accepting repatriation. Once the workers' relevant documents have been prepared by the employer, the repatriation company escorts these workers

14. Pereira (1989).

15. Sim (2005). 
to the airport where they are sent through the immigration gates. These companies are also hired to track down missing workers. ${ }^{16}$

While many of their activities contravene the Penal Code in Singapore—such as wrongful confinement or wrongful restraint - the police do not consider this a criminal offence. ${ }^{17}$ According to local NGOs, the police see migrant workers as "social problems and potential immigration offenders" and are "happy that repatriation companies can perform this function" of forceful repatriation for them. ${ }^{18}$ While the Singapore Police Force have not publicly responded to these claims, the Ministry of Manpower did conduct one round of inspections on two repatriation companies in November 2011 and found no legal violations. ${ }^{19}$ In the same press release, the ministry reiterated that it would not tolerate the use of wrongful restraint and the forceful repatriation of workers with outstanding salary or work-injury claims. First-hand accounts from activists, however, suggest that violations occur on a fairly regular basis. ${ }^{20}$

All the workers I spoke to (both during interviews and at the participant observation stint) were acutely aware of their deportable legal status and were aware that their employers could forcefully deport them at any time. Many demonstrated a clear understanding of their legal vulnerability as a result of the deportation laws they were subject to. Yet they were not unduly concerned by this, as they felt that their respective employers would not do so. It did not appear as if this was due to some inherent trust they had in their respective employers or even a display of machismo. All workers who were currently employed during the interviews and participant observation voiced serious grievances over working conditions. They were also, to varying extents depending on tenure, worried about servicing their recruitment debts (between $\mathrm{S} \$ 2,000$ and $\mathrm{S} \$ 10,000$ ) and providing for their families back home. In order to understand this seemingly contradictory disposition, I examine production-related factors within the workplace which intersect with migrant worker deportability.

\section{THE PRODUCTION PROCESS IN THE CONSTRUCTION INDUSTRY IN SINGAPORE}

The construction industry in Singapore does not only refer to the construction of buildings. It includes a broad range of activities such as: the building, alteration, maintenance, and removal/demolition of fixed structures such as roads, bridges, railways, harbours, cableways, canals, pipelines, tunnels, and viaducts; electrical, water, gas, and telecommunications installation and maintenance; drainage and plumbing workers; and land reclamation, among many others. Due to the varied and diverse nature of the industry, work arrangements are largely heterogeneous. Workers may be deployed to work in large enclosed construction sites or small non-automated workshops. They may be deployed in small autonomous detachments (usually under the charge of a supervisor or foreman) to various open sites around the island or within the premises of clients when doing maintenance work. The duration of each deployment can vary greatly, depending on the nature of the company's

\footnotetext{
16. HOME \& TWC2 (2010); Lim (2011).

17. Basu (2009); HOME \& TWC2, ibid., p. 8.

18. Lim, supra note 16.

19. Ministry of Manpower Singapore (2011).

20. Wham (2011).
} 
work and the size of the construction project. Many contractors have operations on more than one site and may often redeploy or cross-deploy workers based on their overall labour needs.

Despite these variations, there is a degree of consistency within the industry regarding the manner in which work is commanded, delegated, and co-ordinated at various worksites. The industry is highly labour-intensive and relatively un-automated. A very significant proportion of it (96\%) comprises small and medium-sized firms. ${ }^{21}$ Such firms do not have the ability or resources to utilize sophisticated and complex bureaucratic controls to command and coordinate work. Managerial procedures cannot always be easily routinized or institutionalized into systematic administrative structures.

As a result of this, employer strategies of labour control in the industry tend to be largely direct, ad hoc, hierarchical, and highly personalized. As and when projects get awarded, contractors and/or project managers personally delegate tasks to supervisors and foremen who command, instruct, guide, and assist workers at the designated point of production. The hierarchical command and co-ordination of work are based on the positional and personal authority that bosses and supervisors have over their charges. While there are no formalized means for workers to challenge or negotiate supervisory commands, these commands are constantly negotiated on a highly informal and personal basis. The autonomy/informality of supervision as well as the geographically dispersed nature of production plays a crucial role in influencing how deportable workers formulate tactics to deal with the workplace grievances that they face whilst addressing their sense of vulnerability.

\section{TACTICAL ACCOMMODATION AS PROTECTION FROM DEPORTATION}

The interviews and participation observation revealed overwhelming worker grievances over working conditions, particularly low and stagnant wages, legal and illegal wage deductions made by employers, having to pay kickbacks indirectly to employers for employment and contract renewal, as well as the physically demanding and "dirty" nature of their work. In short, these workers felt that their existing employment arrangements required too much physical effort while leaving them with little or no monetary reward to realize their migration objectives. Despite this, at work, workers tend to obey orders based on the personal authority of bosses or other work superiors such as managers and supervisors. These workers were explicitly aware that they had few formal rights and, therefore, lacked the "power" to openly challenge their employers on work conditions. Through their experiences at the worksite and their interactions with other migrant workers, they learn that there is little they can do to directly change the terms of their employment. Workers regard themselves has "power no have," primarily because of their deportable legal status_-"can send back." They see others with resident rights (Singapore citizens or permanent residents) as people who have more "power" because they do higher-status work ("service" or "business" as opposed to menial wage work) and are not deportable.

At the same time, these workers feel that the success of their migration objectives necessarily depends on having a "good relationship" with people who "have power" with their bosses and work superiors being the most immediate manifestation. Hence, every

21. Construction Industry Development Board Singapore (2000). 
worker I interviewed seemed keen to meet or exceed the expectations of their work superiors in terms of the proficiency and timeliness of their work, especially in the first six to nine months of employment. Workers consciously present themselves to work superiors as men who "can do" (willing to work), "can follow" (obedient to orders), and who are "working understand" (competent and proficient). Having established their individual competence and obedience to work superiors, they make informal requests for wage increments, preferential deployments, and contract renewals. At the same time, they take advantage of periods of non-supervised production to engage in forms of "everyday resistances" such as informal output restriction in order to minimize or moderate the amount of energy they put into their work.

Here, I emphasize the tactical aspect of worker obedience. Following de Certeau, ${ }^{22}$ Sargeson understands "tactics" as the way in which less powerful groups use systems of knowledge and practices in ways not intended by their makers "with a view to subversion or carving out a space which they can manoeuvre in." ${ }^{23}$ Workers deliver a façade of obedient and competent work whilst engaging in covert "everyday resistances" for two reasons- to siphon better rewards (wages, tenure, deployments) from work superiors and to avoid open conflict with them. My data show that workers tend to be less successful in accomplishing the former, as they have little political leverage in gaining better terms of work, even informally. However, such forms of tactical accommodation do prove to be particularly useful in preventing employers from using deportation threats and forceful deportation against them. While workers were aware that they could be "send back" or threatened with deportation, they did not believe their employers would do so, at least if they avoided "fighting" with their work superiors. It was their tactical performance of obedience rather than fear that gave them this sense of security.

The vulnerability and tractability of migrant workers as a result of deportation laws are, by themselves, insufficient to explain the prevalence of tactical accommodation among Bangladeshi construction workers. The key aspect of tactical accommodation is that it represents a conscious attempt by these workers as a kind of protection from deportation whilst attempting to renegotiate the terms of work. Workplace politics tend to take this form because of way the deportability of migrant workers intersects with production-related factors - such as the geography of production and specific managerial strategies-in Singapore's construction industry.

The geography of production in this industry includes frequent incidences of small-scale and fairly autonomously supervised work deployments based on the division of labour of construction work and the prevalence of subcontracting. In such instances, points of production are often geographically dispersed as workers are deployed to work in small groups of two to seven. It is important note that points of production in construction are often multiple and often direct supervision is punctuated rather than constant. These production arrangements allow individual workers greater autonomy to regulate the pace and intensity of their efforts. Workers may choose to work faster and exceed the expectations of work superiors to prove their competence; they may choose to step up their efforts during cooler parts of the day while slacking off during the mid-day hours while unsupervised.

22. de Certeau (1984).

23. Sargeson (2001), p. 54. 
Periodic supervision allows them to work slowly and consistently with short regular breaks. Workers are often able to renegotiate deadlines as long as they demonstrate progress in their work and provide justifications that their lack of progress was hampered by factors beyond their control, such as that materials provided were not of the correct specifications, the physical terrain prevented tasks from being completed in a routine manner, machine malfunction, etc. Based on the interviews as well as my own experiences on the job, these come across as common and plausible given that many construction firms (mostly small and medium-sized enterprises) are run quite chaotically. One interviewee even told me that, during a particular work stint, he spent most of his night shifts napping in large iron pipes because supervision was so lax and work was so poorly co-ordinated. ${ }^{24}$ Furthermore, supervisors, who often come from the rank-and-file and share the same grievances as workers, actively collaborate with them to moderate the pace and intensity of work. The point here is that the dispersed nature of production and relatively autonomous supervisory arrangements allow workers the opportunity to redress grievances over working conditions while steering clear of confrontation with their employers.

In terms of managerial strategies, a clear distinction needs to be made between employers' use of deportation threats to direct and command work activities and their use of such threats to counteract worker dissent or resistance. The labour migration literature almost exclusively focuses on the latter. ${ }^{25}$ There is little doubt that this is true in the present context as employers here attempt to suppress worker insubordination with threats, blacklisting, forced deportation, and various forms of physical and mental abuse. However, within the workplace, deportation threats or other forms of direct coercion are not the primary means by which employers make migrant workers perform work tasks. This is not due to employers' incapability or reluctance to do so. Rather, this comes about because workers are constantly pre-empting deportation threats through the aforementioned tactics of accommodation. This effectively allows employers to utilize the obedience orientation of workers to direct work with less effort and complication.

Deportation threats and forced deportation are used strategically across the industry in order to prevent or pre-empt worker agitation or insubordination. In an interview with a former manager of a construction firm, the respondent outlined how the company dealt with "problem" workers. First, the worker will be given a simple order by a work superior to "get in line." If the worker does not comply with this order, the managing director will approach the worker for "counselling." At this point, the manager will attempt to find out what problems the worker is facing. During "counselling," the manager makes an attempt to persuade the worker to do as he is told- "we will tell the worker that he is here to make money for his family, and if he wants to continue doing this, he must know how to follow orders." It is only when persuasion fails that the manager rings up a repatriation company in order to forcibly deport the "problem" worker- "if they don't want to listen, then they can go back to where they came from." ${ }^{26}$ In short, deportation threats and forced deportation are not used indiscriminately by employers to set their workers to work; they are used strategically when obedience is not forthcoming from individual workers.

24. Interview, 26 April 2012.

25. Sassen (1988); Mitchell (1996); Arnold \& Hewison, supra note 1; Binford supra note 2.

26. Interview, 10 January 2012. 
These production-related factors - the often dispersed geography of production, autonomous supervisory arrangements, and the strategic use of direct coercion-serve as an outlet of sorts in releasing tensions between workers and employers over working conditions. As workers experience a sense of vulnerability due to their deportable status within a fairly autonomous work regime, opportunities for confrontation and agitation are foreclosed while opportunities for tactical accommodation are opened up. While deportability inhibits workers from overtly confronting managerial control, it also makes it necessary for them to tactically produce a façade of obedience in order to protect their migration objectives.

\section{THE COMPULSIONS OF CONFRONTATION AND DESERTION}

While workers consciously avoid confrontation with employers in order to protect themselves from forced deportation, under certain workplace conditions, confrontation becomes necessary. This tends to happen when working conditions deteriorate to the point that workers are unable to effectively exercise tactical accommodation and disputes become inevitable. Employer-worker relations tend to deteriorate in times of economic crisis or downturn, rising cost pressures for contractors, or mismanaged work injuries. Under such circumstances, migrant workers are unable to exercise tactical accommodation and are drawn into disputes over unpaid wages, increased wage theft, intensified work regimes, underdeployment (no work, no pay), and work-injury compensation. Within these disputes, workers are compelled to confront their employers and demand redress. Such confrontations invariably unleash the coercive power of employers who respond with deportation threats, physical and verbal abuse, and, finally, forced deportation. It is particularly instructive that employers use these forms of coercion specifically as a means to resolve workplace disputes rather than to set their workers to work.

Construction contractors, a majority of which are small and medium-sized enterprises operating within a highly competitive industry, have been faced with rising cost pressures due to the unrelenting rise in foreign-worker levy rates (payable to the government) and dormitory rates (to house their migrant workers). Contractors have responded to these cost pressures by attempting to transfer some of these costs onto their workers in the form of wage deductions and stagnating or depressing basic wage rates as well as attempting to intensify work regimes to achieve greater productivity from workers. As supervision at work becomes more intense and wage deductions prove to be overbearing, most workers see little point in pursuing tactical accommodation. Their immediate objectives of migration-servicing debt and sending money home to their families - are immediately threatened when their monthly earnings are undercut by increasing wage deductions. On top of that, many workers have to contend with physical tiredness and fatigue as the intensifying of work regimes leave them little leeway in engaging in "everyday resistances."

During economic downturn or crisis, migrant workers are not deployed or are sparsely deployed to work over long periods of time. This is often because their employers do not have sufficient jobs or because projects have been delayed or cancelled. Many contractors (particularly labour-supply firms) have little qualms about bringing in surplus labour as they able to profit from kickbacks via recruitment fees that workers pay. During the GFC between 2008 and 2009, local NGO HOME recorded about 440 complaints of underdeployment out of 1,047 total complaints between April 2008 and March 2009. In contrast, before the GFC, 
earlier records revealed an almost negligible number of similar cases. Underdeployment proves to be a major problem for affected workers, since, being daily rated, they are not paid at all when not deployed to work. NGO case-file reports also reveal that, when not deployed and not earning anything, workers are still subject to various wage deductions mandated by the company such as for rent, food, and utilities. These deductions are carried over to months when workers are deployed. This leaves affected workers with negligible or no earnings for several months in a row. Under such circumstances, tactical obedience becomes unfeasible.

Under Singapore's work-injury compensation laws, all workers injured in the course of work are entitled to a range of compensatory benefits which are ultimately provided for by compulsory insurance policies that employers have to take up for their employees. Despite this, a number of contractors are often keen to conceal work injuries for a range of reasonsreporting the injury might lead to further investigations into the company's safety practices, employers are concerned about increases in insurance premiums, the insurance policy has lapsed, they are concerned about having to house and feed an unproductive worker, or they simply believe the injury is not serious or the worker is faking injury. NGO reports and interview data also reveal that employers also prevent workers from lodging claims of their own by not providing workers with suitable medical attention, colluding with company doctors, and confiscating the medical certificates of workers. Threats are also made to other workers who have personally witnessed these work accidents. Under these circumstances, workers are unable to engage in tactical obedience as they feel that their right to access workinjury compensation is undermined or doing so would expose them to more physical pain.

When such disputes arise, workers are unable to engage in tactical accommodation. Constant and intrusive supervision closes off spaces for workers to informally renegotiate the terms of work, heightening existing tensions over wage theft and harsh work regimes. Workers are also unable to use such tactics when they are not deployed to work, as there are barely any terms of work to speak of when there is no work, or pay. An injured worker who is ordered to return to work or deprived of medical care feels that his physical wellbeing is at stake and cannot tactically accommodate such orders. Furthermore, these workers have no alternative recourse in the midst of such disputes - contractor firms do not have formal complaints mechanisms, collective bargaining platforms are inaccessible to these workers, and they face major obstacles in individually accessing labour justice at the Labour Ministry, not least because of their deportable status.

Workers in such situations, which are neither routine nor exceptional, feel compelled to confront their bosses with their grievances. This is in spite of their ordinarily conservative orientation in avoiding open conflicts with work superiors. Workers usually often make initial pleas to their bosses to make improvements to work regimes. These pleas are almost always ignored or dismissed. Workers then go on to make more firm demands, often verbally but also in writing to bosses or managers. One respondent, Shahin, for instance, demanded that salary deductions for "security deposits" and utility bills be repealed and refunded back to him when he requested an audience with his managing director. ${ }^{27}$ Kamrul and his eight coworkers, who were paid below statutory rates for overtime and rest-day work, asked their employer to restore these rates to the statutory level and to back-pay them for previous

27. Interview, 25 December 2011. 
months' work. ${ }^{28}$ In another case, about 100 Bangladeshi workers got a local "friend" to help them write a letter of demand, signed by all 100 workers, to management after going unpaid for three months. After outlining the problems faced by their families in Bangladesh, the letter demanded that all owing wages be paid "within [a] short time" and wages, in future, were to be paid punctually on the tenth day of every month. Their employer ignored these demands and the workers subsequently approached HOME for legal assistance. ${ }^{29}$ Workers, usually out of frustration, sometimes combine these demands with overt demonstrations of disobedience at work such as work stoppages and truancy.

Aside from one specific documented case, worker confrontation and disobedience inevitably unleash the coercive power of employers who respond with deportation threats, physical intimidation, and finally forced deportation. It is worth emphasizing that these employer strategies are primarily used to resolve workplace disputes (such as those mentioned) rather than to ordinarily direct work activities. Al Amin's demands for proper medical attention and work-injury compensation were met with an ultimatum from his production manager, who told him, "Amin, do you want to go back to Bangladesh or do you want to stay in Singapore to work and earn money for your family? If you want to stay then you must go back to work!"30 Masud's employer threatened to "throw" him back to Bangladesh "like rubbish." ${ }^{, 31}$ When deportation threats are made, workers are told not only that they will be instantly deported if they do not follow orders, but that they will also be blacklisted and never be allowed back into Singapore.

When other methods of coercing recalcitrant workers back in line fail, employers attempt to forcefully deport them. Employers cannot simply terminate the employment of migrant workers-they are held legally responsible by the Labour Ministry for repatriating workers who have been terminated or have ended their terms. Employers may terminate a worker's work permit at any time but they are legally required to repatriate the worker within seven days of this termination or the $\$ \$ 5,000$ bond with the ministry may not be refunded. Employers, therefore, call in repatriation companies to take "problem" workers into custody from their dormitories or worksites awaiting repatriation. Physical and verbal intimidation is often used on workers who refuse to comply. Shahid, for instance, had his medical certificates confiscated and found himself locked up in a room on his company's premises for days while being subject to constant verbal threats by his employer. ${ }^{32}$ Mohamed Asadullah was abducted by men from a repatriation company right outside the Ministry of Manpower building after lodging a complaint for unlawful wage deductions. ${ }^{33}$ Hashim had his mobile phone seized from him and was subjected to physical and verbal threats whilst locked away at the premises of a repatriation company. ${ }^{34}$

In fear and desperation, workers desert their employers; they discreetly move away from the worksite or dormitory to another place-their friends' dormitories or the streets of the Little India district where Bangladeshi workers usually congregate-where their employers

\footnotetext{
28. HOME case report, 17 August 2009.

29. HOME case report, 12 July 2010.

30. Interview, 28 December 2011.

31. HOME case report, 11 October 2010.

32. Interview, 29 December 2011.

33. Transient Workers Count Too (2011).

34. Interview, 28 December 2011.
} 
can neither control nor reach them. Some workers pre-empt forced deportation by deserting even before they are intimidated or threatened. Other workers, like Muqbul, are tipped off by their co-workers or even supervisors when the repatriation staff is on their way to take the worker into custody. ${ }^{35}$ Some workers manage to escape while being escorted from their dormitories by the repatriation company. Some workers who fail to escape until they are escorted to the airport either refuse to go through immigration gates or refuse to board the flight after clearing immigration. Some workers who are unable to escape from repatriation companies ring up the police for assistance but are often told to comply and be repatriated. Some manage to contact NGO helpdesks to request assistance. In such cases, NGO staff would go directly to these repatriation companies to negotiate the release of workers. Should negotiations fail, NGO staff would go to the airport to assist workers in refusing to enter immigration gates. Often, this leads to confrontations between activists and repatriation staff. The former often secure the release of workers in "custody" by signing an "indemnity" with the repatriation company bearing responsibility for the employer's security bond should the worker go "missing." However, there is little evidence to show that such "indemnities" have ever been legally enforced by repatriation companies or employers. It is likely that such "indemnities" are used by repatriation companies to placate their clients when activist successfully obstruct forceful repatriation. Nonetheless, these indemnities have proved useful for NGOs in getting workers released from the custody of repatriation companies.

\section{CONTENTIOUS POLITICS, MITIGATING DEPORTABILITY}

Deserting workers either stay on to find work in Singapore as overstayers or they seek out other social actors - the police, their recruitment agents, friends, relatives, lawyers, NGOsto assist them with their predicament. Here, I focus exclusively on the latter. In such circumstances, they get very limited assistance from those mentioned-the police often tell them to return to their employers, their agents refuse to reimburse their recruitment fees, their friends and relatives might provide them with a place to stay, some meals, and an "illegal" day job but little else in terms of addressing their continued deportability, lawyers will only assist those with work-injury compensation issues. Through contacts provided by friends or lawyers, many deserting workers find their way to migrant worker NGOs like HOME and TWC2. These NGOs assist workers with their daily needs-HOME has two worker shelters while TWC2 runs a soup kitchen in Little India that is open for lunch and dinner several times a week. More significantly, NGOs provide legal assistance to workers and use these cases of assistance to advocate for the reform of migrant labour laws. In both cases, the deportability of migrant workers is somewhat mitigated.

Case workers and volunteers at these NGOs translate worker grievances over work injuries, underdeployment, and wage theft into formal complaints at the Labour Ministry. By querying workers on their grievances, case workers attempt to find out which particular labour laws or regulations have been breached by employers. They then proceed to assist the worker to lodge relevant claims to the ministry such as work-injury claims, salary claims, and complaints regarding the infringement of EFMA regulations. In all cases, once the formal claim is registered with the ministry, workers are given the legal right to remain in the

35. Interview, 28 December 2011. 
country until the resolution of their cases through "special passes"- a visa renewable on a weekly or fortnightly basis. These "special passes" are given out to workers based on their new (but still temporary) legal status as claimants (for wages or work-injury compensation) or state witnesses (for employer violations of EFMA). The temporary stay can range from any between several weeks (salary disputes) to over one year (work-injury cases, EFMA cases). State witnesses for EFMA cases are usually allowed to sign on with a ministrysponsored Temporary Job Scheme (TJS) where they may look for temporary (six-month) legal jobs which can be made permanent subject to a number of the ministry's conditions.

While immediate legal assistance in this form mitigates the deportability of individual workers, these cases provide NGOs with the impetus to lobby the ministry for reforms to deportation laws. Since 2009, NGOs have demanded that repatriation companies be outlawed and prosecuted for wrongful confinement and forced repatriation of migrant workers. They have also called for the Labour Ministry to repeal all work-permit regulations (under EFMA) that give employers the unilateral right to cancel the work permit of workers as well as the liberalization of the current Change-of-Employer (COE) regulations to allow existing migrant workers to change employers without having to be repatriated. While these NGOs were unable to mobilize migrant workers or public opinion to their cause, they drew on a mass of case work that they had amassed over several years which documented how employers used repatriation companies to resolve workplace disputes in a way which violated statutory standards.

Of the few formal rights they have, temporary migrant workers are allowed to lodge complaints regarding wage disputes, work injuries, and illegal deployments at the ministry. However, their deportable status poses an obstacle that inhibits them from accessing these rights. NGO direct services come in the form of legal assistance in lodging claims in the face of deportation threats and interventions into everyday practices of deportation. These allow workers to access these rights by mitigating their vulnerability to deportation and forestalling their actual deportation. Furthermore, by lobbying the ministry to reform labour laws, NGOs put pressure on the state to broaden migrant worker rights and revise the latter's status as discardable political subjects.

The GFC spill-out of 2008/09 proved to be a shot in the arm for NGO advocacy. During this period, thousands of migrant workers (mostly Chinese and Bangladeshis) from the construction and shipbuilding industry deserted their workplaces after confrontations over unpaid wages, underdeployment, and alleged employer kickbacks resulted in deportation threats from employers. Large groups of workers approached NGOs for assistance while others staged a sit-in outside the Ministry of Manpower building in Havelock Road demanding redress. The ministry initially called for the immediate deportation of all underdeployed workers. However, as the spill-out intensified as more groups of workers deserted, the ministry decided to grant affected workers a one-month grace to source for alternative employment within the same stipulated industry. This one-off concession gave NGOs the drive to lobby the ministry further to grant conditional COEs to all migrant workers engaged in employment disputes with their employers so that they would not have to be deported. Closed-door advocacy to ministry officials was intensified following the GFC spill-out while NGOs used existing documentation of forced repatriation cases to inform the US Department of State Trafficking in Persons Report and Singapore's first Universal Periodic Review by the UN Human Rights Council. 
Since then, the ministry has moved to create additional employment offences such as the illegalization of kickbacks for employment and compulsory no-work pay. They have also revised the existing $\mathrm{COE}$ regulations to allow workers whose tenure has expired to seek new jobs in the country without being repatriated. NGOs have criticized the latter for being insufficient to protect migrant workers from forced deportation and employer abuse. Nonetheless, the expansion of the COE system is particularly significant. Under the old COE system, workers were only (if ever) granted a COE under very strict conditions-the most significant one being that their existing employer had to agree to it. Workers who have their employment prematurely terminated by their employer, often due to employment disputes, would, thus, have to return to their countries of origin and fork out another huge sum of money in order to secure a new job in Singapore. Under the revised COE framework, employer consent is not required. Workers may be granted COEs, at the ministry's discretion, once they complete their current term of employment or, in cases of underdeployment, where employers do not have sufficient jobs to sustain their migrant workforce. Under such circumstances, workers do not need to return to their countries of origin in order to secure a contract with a new employer. While the new regulations could have negative implications for worker empowerment in the workplace, they significantly temper the ease with which these workers can be used and discarded.

At the same time, it is equally important to note that the tweaking of labour laws does not necessarily constitute a concession to the welfare of migrant workers. Rather, this is a form of "technocratic problem solving" where existing tensions between employers and migrant workers over working conditions can be managed through administrative means. ${ }^{36}$ State-sponsored administrative channels for contestation are being broadened in order for migrant workers to politically participate as individual complainants rather than as andependently mobilized collective entity. The additional employment offences and a revised COE framework will allow disputes to be managed through the administrative channels of the ministry rather than through spontaneous collective action (as witnessed during the GFC) or independent NGO advocacy. In this sense, mitigating migrant worker deportability through minor reforms provides for a depoliticized resolution to workplace disputes without actually addressing the core tensions in the workplace which give rise to these disputes.

\section{CONCLUSION}

State deportation laws render temporary migrant workers as "use-and-discard" economic subjects with few formal rights. While these laws severely undermine the political personhood of migrant workers, the deportable status of these workers may contribute towards civil society efforts to contest state constructions of these workers as disposable economic subjects. This article has stressed the importance of the micro-politics of the workplace as the site through which issues of deportability and practices of deportation shape migrant worker agency. Articulated together with a range of political-economic factors, deportability engenders a range of worker tactics to deal with existing workplace grievances. Responses such as tactical accommodation and confrontation/desertion come about under different workplace conditions depending on how migrant worker deportability intersects with

36. Rodan \& Jayasuria (2007). 
production-related factors, such as production geography and employer control strategies, that govern the terms of work.

These different tactics, in turn, have varied implications for the shape of migrant labour politics in the country in terms of broader civil society pressures to reform migrant labour laws. Certain outcomes of workplace conflicts, particularly confrontation and desertion rather than tactical accommodation, allow civil society groups to contest state constructions of temporary migrant workers as disposable persons without political rights. Civil society pressure, in turn, leads to state responses in revising the legal status of these workers. While deportation laws inhibit migrant workers from accessing the few formal rights they are endowed with, the reforms introduced by the Manpower Ministry encourage workers to make contestations as individual complainants within the state's bureaucratic mechanisms rather than as collectively mobilized actors or through independent NGO advocacy. The state's belated but limited expansion of migrant worker political personhood as individualized complainants through the mitigation of deportability, therefore, serves to depoliticize enduring worker grievances over working conditions.

\section{REFERENCES}

Arnold, Dennis, \& Kevin Hewison (2006) "Exploitation in Global Supply Chains: Burmese Migrant Workers in Mae Sot, Thailand," in K. Hewison \& K. Young, eds., Transnational Migration and Work in Asia, London and New York: Routledge, 165-90.

Bal, Charanpal S. (2015) "Production Politics and Migrant Labour Advocacy in Singapore." 45 Journal of Contemporary Asia 219-42.

Basu, Radha (2009) "Holding Area Is a Room in the Office: Close Tabs Kept on Workers in Case They Try to Run Off," The Straits Times, 31 January.

Binford, Leigh (2009) "From Fields of Power to Fields of Sweat: The Dual Process of Constructing Temporary Migrant Labour in Mexico and Canada." 30 Third World Quarterly 503-17.

Buckley, Michelle (2013) "Locating Neoliberalism in Dubai: Migrant Workers and Class Struggle in the Autocratic City." 45 Antipode 256-74.

Castells, Manuel (1975) "Immigrant Workers and Class Struggles in Advanced Capitalism: The Western European Experience." 5 Politics and Society 33-66.

Castles, Stephen, \& Godula Kosack (1973) Immigrant Workers and Class Structure in Western Europe, London: Oxford University Press.

Construction Industry Development Board Singapore (2000) Census of the Construction Industry 2000, Construction Economics and Resources Unit, Construction Industry Development Board, Singapore.

de Certeau, Michel (1984) The Practice of Everyday Life, translated by Steven Rendall, Berkley: University of California Press.

de Genova, Nicholas P. (2005) Working the Boundaries: Race, Space and "Illegality" in Mexican Chicago, Durham and London: Duke University Press.

Government of Singapore (1991) "Employment of Foreign Manpower Act (Chapter 91A), Amended 9 November 2012, Attorney-General's Chambers," online <http://statutes.agc.gov.sg/aol/search/ display/view.w3p;page =0; query=DocId\%3Ad07a73ca-043a-4531-8132-357598e0a9ab\%20\% 20Status\%3Ainforce\%20Depth\%3A0;rec=0> (last accessed 15 July 2013).

Hsia, Hsiao-Chuan (2009) "The Making of a Transnational Grassroots Migrant Movement." 41 Critical Asian Studies 113-41.

Humanitarian Organization of Migration Economics (HOME) and Transient Workers Count Too (TWC2) (2010) Justice Delayed, Justice Denied: The Experiences of Migrant Workers in Singapore, Singapore: HOME and TWC2. 
Lim, Philip (2011) "Migrant Workers Hunted Down in Singapore," The Jakarta Globe, 3 August.

Liow, Eugene Dili (2011) "The Neoliberal-Developmental State: Singapore as Case-Study." 38 Critical Sociology 1-24.

Ministry of Manpower Singapore (2011) "Joint Proactive Enforcement Inspections on Repatriation Companies," Press Release, 14 November.

Mitchell, Don (1996) The Lie of the Land: Migrant Workers and the California Landscape, Minneapolis: University of Minnesota Press.

No Author (1977) "Employment Passes for These Alien Workers," The Straits Times, 28 December.

No Author (1989) "Boon Heng: Govt Considering 'Final Amnesty' Appeal," The Straits Times, 11 July.

Pereira, Brandan (1989) "470 Illegal Thai Workers Sent Back in Past 72 Hours," The Straits Times, 18 March.

Rodan, Garry, \& Kanishka Jayasuria (2007) "The Technocratic Politics of Administrative Participation: Case Studies of Singapore and Vietnam." 14 Democratization 795-815.

Sargeson, Sally (2001) "Assembling Class in a Chinese Joint Venture Factory," in J. Hutchison \& A. Brown, eds., Organising Labour in Globalising Asia, London: Routledge.

Sassen, Saskia (1988) The Mobility of Labor and Capital: A Study in International Investment and Labor Flow, Cambridge and New York: Cambridge University Press.

Sassen-Koob, Saskia (1981) “Towards a Conceptualization of Immigrant Labor.” 29 Social Problems 65-85.

Sim, Chi Yin (2005) “They're Runaway 'Bounty Hunters'," The New Paper, 26 November.

Taylor, Charles (1985) Philosophical Papers: Volume 1, Human Agency and Language, Cambridge: Cambridge University Press.

Transient Workers Count Too (2011) "Twice Abducted by Repatriation Agents, Asadullah Goes Home Poorer than when He Arrived," online <http://twc2.org.sg/2011/12/31/twice-abductedby-repatriation-agents-asadullah-goes-home-poorer-than-when-he-arrived/ $>$ (last accessed 5 February 2015).

Wham, Jolovan (2011) "Repatriation Companies-Manpower Minister's Response Belittles the Efforts of Migrant Workers," online <http://www.theonlinecitizen.com/2011/11/repartriation-companiesmanpower-ministers-response-belittles-the-efforts-of-migrant-workers/> (last accessed 26 June 2015).

Yeoh, Brenda (2006) "Bifurcated Labour: The Unequal Incorporation of Transmigrants in Singapore." 97 Tijdschrift voor Economische en Sociale Geografie 26-37. 